\title{
Interspecific variation in patterns of adhesion of marine fouling to silicone surfaces
}

\author{
ERIC R. HOLM ${ }^{1}$, CHRISTOPHER J. KAVANAGH ${ }^{2}$, ANNE E. MEYER ${ }^{3}$, DEBORAH WIEBE ${ }^{4}$, \\ BRIAN T. NEDVED ${ }^{5}$, DEAN WENDT ${ }^{6}$, CELIA M. SMITH ${ }^{7}$, MICHAEL G. HADFIELD $^{5}$, \\ GEOFF SWAIN $^{2}$, CHRISTINA DARKANGELO WOOD ${ }^{8}$, KATHRYN TRUBY $^{8}$, \\ JUDITH STEIN $^{8}$ \& JEAN MONTEMARANO ${ }^{1}$
}

\author{
${ }^{1}$ Naval Surface Warfare Center, Carderock Division, West Bethesda, Maryland, ${ }^{2}$ Department of Marine E Environmental \\ Systems, Florida Institute of Technology, Melbourne, Florida, ${ }^{3}$ Industry/University Center for Biosurfaces, University at \\ Buffalo, New York, ${ }^{4}$ Altran Corporation, Boston, Massachusetts, ${ }^{5}$ Kewalo Marine Laboratory, University of Hawaii, \\ Honolulu, Hawaii, ${ }^{6}$ Biological Sciences Department, California Polytechnic State University, San Luis Obispo, California, \\ ${ }^{7}$ Department of Botany, University of Hawaii, Honolulu, Hawaii, and ${ }^{8}$ GE Global Research Center, One Research Circle, \\ Niskayuna, New York, USA
}

\begin{abstract}
The adhesion of six fouling organisms: the barnacle Balanus eburneus, the gastropod mollusc Crepidula fornicata, the bivalve molluscs Crassostrea virginica and Ostrea/Dendrostrea spp., and the serpulid tubeworms Hydroides dianthus and H. elegans, to 12 silicone fouling-release surfaces was examined. Removal stress (adhesion strength) varied among the fouling species and among the surfaces. Principal component analysis of the removal stress data revealed that the fouling species fell into two distinct groups, one comprising the bivalve molluscs and tubeworms, and the other the barnacle and the gastropod mollusc. None of the silicone materials generated a minimum in removal stress for all the organisms tested, although several surfaces produced low adhesion strengths for both groups of species. These results suggest that fouling-release materials do not rank (in terms of adhesion strength) identically for all fouling organisms, and thus development of a globally-effective hull coating will continue to require testing against a diversity of encrusting species.
\end{abstract}

Keywords: Adhesion strength, fouling organisms, silicone surfaces, fouling-release, interspecific variation

\section{Introduction}

The accumulation of fouling on a ship's hull significantly degrades performance by increasing drag and fuel consumption, and decreasing maximum speed and cruising range (Woods Hole Oceanographic Institution, 1952). Currently, broad-spectrum toxicants, including organic 'booster' biocides, are used to control hull fouling. These compounds are under increasing regulatory scrutiny. Novel non-toxic hull coatings are needed to assure continued efficient operation of ships, while also protecting the environment.

One of the reputedly non-toxic alternatives to the toxic hull coatings currently in use employs the fouling-release strategy. Silicone fouling-release coatings allow fouling to accumulate, but prevent its firm attachment (Callow et al. 1986; Swain \&
Schultz, 1996; Vincent \& Bausch, 1997; Schultz et al. 1999). Poor adhesion of attached organisms is caused by the surface and material properties of the coating, including low surface energy and elastic modulus (see Vincent \& Bausch, 1997 and Brady \& Singer, 2000 for reviews; Chaudhury et al. 2005), and increased coating thickness (see Brady \& Singer, 2000 for review; Chaudhury et al. 2005; Wendt et al. 2006), that affect the fracture of the bond between fouling organism and coating (Brady \& Singer, 2000). Ideally, adhesion of the attached organisms is sufficiently weak that fouling is sloughed from the hull as a result of hydrodynamic forces generated by the movement of the ship through the water ('hydrodynamic self-cleaning', Schultz et al. 1999).

The community of organisms that occurs as fouling on ships' hulls is enormously diverse (for example, WHOI, 1952; Carlton \& Hodder, 1995; 
Gollasch, 2002; Godwin, 2003). This great diversity presents a significant challenge to the development of fouling-release materials. Encrusting species utilise a variety of adhesives in fixing to a surface (Naldrett \& Kaplan, 1997; Brady \& Singer, 2000; Wiegemann, 2005; Smith \& Callow, 2006). It may not be possible for a fouling-release hull coating to reduce substantially the strength of adhesion of all organisms to which it is exposed, to the point where hydrodynamic forces on the attached fouling cause detachment and complete self-cleaning. Challenging a novel foulingrelease material with a diversity of species may be necessary to determine if the material is likely to be globally effective.

The adhesion of six fouling species (a barnacle, a gastropod mollusc, two bivalve molluscs, and two serpulid tubeworms), to 12 silicone surface treatments that may have promise as fouling-release materials, was examined at four field test sites. The goals of the field tests were to determine whether there were significant differences among the silicone surface treatments in the adhesion of the fouling species common at each site, and whether the pattern in any variation in adhesion observed was similar across fouling organisms.

\section{Materials and methods}

The results reported here arise from field tests conducted as part of a research program aimed at developing improved fouling-release polymers through incorporation of silicone oils (Truby et al. 2000; Darkangelo Wood et al. 2000; Kavanagh et al. 2003; Stein et al. 2003). The field tests were designed to examine two hypotheses: i) adhesion of individual fouling species does not vary across the 12 silicone surface treatments, and ii) if variation across the surface treatments exists, the pattern of that variation is similar among the fouling species tested.

\section{Surface treatments}

Performance, in terms of adhesion of fouling organisms, was examined for 12 silicone surfaces. The surfaces were based on the duplex foulingrelease coating system developed by Griffith (1995) at the US Naval Research Laboratory. This coating system consists of an epoxy anticorrosive layer, overcoated with a toughening layer (tie coat) of a silicone-styrene butylacrylate polymer blend, followed by a silicone top coat. The silicone top coats were generated from two different polydimethylsiloxane elastomer bases (RTV $11^{\mathbb{E}}$ and a silica-filled base), variously modified by addition of silicone oils (Table I and Table II, see also Kavanagh et al. [2003] and Stein et al. [2003] for details). In one
Table I . Silicone surfaces used in the field tests.

\begin{tabular}{lcl}
\hline Surface & Tie coat & Top coat \\
\hline 1 & $\mathrm{~J}-501$ & RTV 11 \\
2 & $\mathrm{~J}-501$ & RTV $11+10 \%$ SF1154 \\
3 & $\mathrm{~J}-501$ & SFB $+10 \%$ SF1154 \\
4 & $\mathrm{~J}-501$ & RTV $11+10 \%$ DBE224 \\
5 & $\mathrm{~J}-501$ & RTV $11+10 \%$ DMSC15 \\
6 & $\mathrm{~J}-501$ & SFB $+10 \%$ DMSC15 \\
7 & $\mathrm{~J}-501$ & SFB $+10 \%$ SF1147 \\
8 & $\mathrm{~J}-501$ & RTV $11+10 \%$ SF1147 \\
9 & $\mathrm{~J}-501$ & RTV $11+5 \%$ DBE224 \\
& & $+5 \%$ SF1154 \\
10 & $\mathrm{~J}-501$ & RTV $11+10 \%$ C439-47 \\
11 & $\mathrm{~J}-501$ & RTV $11+10 \%$ C439-53 \\
12 & $\mathrm{~J}-501+10 \%$ CMS222 & RTV 11 \\
\hline
\end{tabular}

The entry for top coat represents the silicone elastomer base, with addition ( $\%$ by weight) of silicone fluid. The tie coat, as opposed to the top coat, of surface \#12 was modified by addition (\% by weight) of silicone fluid. SFB, silica-filled base. Silicone fluids SF1154 and SF1147 were obtained from GE Silicones (Waterford, NY, USA); other oils were supplied by Gelest, Inc. (Morrisville, PA, USA).

Table II. Silicone fluids used as additives in the surface treatments described in Table I.

\begin{tabular}{ll}
\hline Additive & Description \\
\hline C439-47 & $\begin{array}{l}\text { Tethered diphenyldimethylsiloxane } \\
\text { C439-53 }\end{array}$ \\
$\begin{array}{c}\text { Tethered carbinol functional } \\
\text { diphenyldimethylsiloxane }\end{array}$ \\
CMS222 & $\begin{array}{c}\text { Carbinol functional methyl siloxane, } \\
\text { dimethylsiloxane copolymer }\end{array}$ \\
DBE224 & $\begin{array}{c}\text { Dimethylsiloxane-ethylene oxide block copolymer, } \\
\text { 25\% non-siloxane }\end{array}$ \\
DMSC15 & $\begin{array}{c}\text { Carbinol (hydroxyl) terminated } \\
\text { polydimethylsiloxane, 20\% non-siloxane }\end{array}$ \\
SF1147 & Decylmethylsiloxane (butylated aryloxy propyl) \\
& methyl siloxane copolymer \\
SF1154 & Polydiphenyldimethylsiloxane \\
\hline
\end{tabular}

See also Table I in Kavanagh et al. (2003).

surface treatment (\#12), the tie coat, rather than the top coat, was modified by the addition of oil. The duplex system was applied to the front and back of $25.4 \times 30.5 \mathrm{~cm}$ steel panels, using standard airless spray equipment.

\section{Exposure sites}

Two panels of each of the 12 experimental surfaces were immersed at four test sites: two sites at the head of the Narragansett Bay, Massachusetts (NE1, NE2); the Florida Institute of Technology's exposure and testing platform in the Indian River lagoon, Florida; and the University of Hawaii's exposure site on Ford Island in Pearl Harbor, Oahu, Hawaii. Environmental conditions and species composition of the fouling community varied among these locations. Both test sites in Massachusetts occur in temperate estuaries, 
with water temperatures ranging from $4^{\circ} \mathrm{C}$ in the winter to $24^{\circ} \mathrm{C}$ in the summer, and salinities from $25 \%$ to $31 \%$ (Darkangelo Wood et al. 2000). Fouling at these sites is strongly seasonal, with most recruitment occurring during the spring and summer (Darkangelo Wood et al. 2000). Common fouling organisms include encrusting bryozoans, tunicates, sponges, and the gastropod Crepidula fornicata $\mathrm{L}$. (Darkangelo Wood et al. 2000). C. formicata, the American slipper limpet, is a sedentary gastropod that fouls both primary (for example, trash racks, intake bays and tunnels of power plant systems [D. Wiebe, personal observation]) and secondary substrata (for example, mussel shells [Thieltges, 2005]). In the north-eastern US, coverage of two species of Crepidula can reach $100 \%$ on static power plant structures painted with fouling-release coatings (D. Wiebe, personal observation). As an epibiont on mussels, C. fornicata can reach densities of up to $2000 \mathrm{~m}^{-2}$ (Thieltges, 2005). The test platform in Florida is located in an estuary, where salinities range from 15-36\% depending on the season and occurrence of rainfall. Mean water temperature varies from approximately $20^{\circ} \mathrm{C}$ in the winter to $30^{\circ} \mathrm{C}$ in the summer, and tidal currents and wave action are minimal (Swain et al. 1998). Settlement of fouling organisms, and species structure of the fouling community, is affected by season of the year (Swain \& Schultz, 1996). Common fouling organisms include the barnacle Balanus eburneus Gould, the oyster Crassostrea virginica Gmelin, the serpulid tubeworm Hydroides dianthus Verrill, and encrusting bryozoans. At the University of Hawaii's exposure site, the temperature $\left(24-27^{\circ} \mathrm{C}\right)$ and salinity (34$35 \% 0$ ) are relatively constant (Darkangelo Wood et al. 2000). The location experiences little current or wave action. The fouling community is extremely diverse and exhibits no strong seasonality (Holm et al. 2000). Important fouling organisms include the serpulid tubeworm Hydroides elegans Haswell, various species of oyster including Ostrea hanleyana Sowerby, Dendrostrea sandvichensis Sowerby, and Crassostrea virginica Gmelin, and several species of sponges, colonial tunicates, and encrusting bryozoans.

Evaluation of panels commenced in July 1997 for the Florida and Massachusetts sites, and in August 1997 for the Hawaii site, and measurements were taken for approximately 2 years thereafter.

\section{Adhesion of fouling organisms in shear}

The removal stress required to detach fouling organisms from the silicone test surfaces was measured following the standard methodology described in ASTM D 5618-94 (Anonymous, 1997) and Swain and Schultz (1996). In this method, force is applied to the base of an adult fouling organism, using a handheld force measuring device, at a rate of approximately $4.5 \mathrm{~N} \mathrm{~s}^{-1}$ and parallel to the surface of the test material. The force at which the organism detaches from the surface is recorded, and removal stress is calculated by dividing this force by the area of attachment of the organism. If during removal a substantial proportion $(>10 \%)$ of the organism's attachment structure (for example, a barnacle's base plate) remains adhered to the test material, the datum is discarded. Removal stress measured in this way is typically independent of the attachment area of the fouling organism (Kavanagh et al. 2001). At the Hawaii test site, procedures for estimating basal area were modified slightly to allow measurement of removal stress for tubeworms (Holm et al. 2000). At the Florida test site, basal areas of fouling organisms were measured directly from scanned images (Kavanagh et al. 2001). All forces measured were pooled across sampling dates, panel faces, and replicate panels before analysis. No tests for temporal variation in removal stress were conducted.

\section{Statistical analysis}

Removal stresses were heteroscedastic in all but one case (C. fornicata from site NE2). Transformation did not improve the homogeneity of the variances. Consequently, the non-parametric Kruskal-Wallis test $(H$ statistic) was used to examine differences in removal stress among surface treatments (hypothesis 1). Separate tests were conducted for each organism measured at each site.

Spearman rank correlation coefficients were calculated to compare removal stresses between organisms and between sites. All correlation calculations were based on the mean removal stress for a particular organism on a particular surface treatment. Principal component analysis (PCA; Manly, 1986) was used to produce groupings of the fouling organisms tested, in terms of the mean shear stress required to remove them from the surface of each of the 12 experimental materials. The correlations and PCA enabled examination of differences among species in the patterns of variation in removal stress they exhibited across surfaces (hypothesis 2). PCA may also be a useful technique for identifying surface treatments to which several types of fouling organisms adhere poorly.

All statistical analyses were conducted using SAS/ STAT (SAS Institute Incorporated, 1989).

\section{Results}

Comparisons among surface treatments

Removal stresses were collected for six species of fouling organisms: the gastropod mollusc Crepidula 
fornicata at sites NE1 and NE2 in Massachusetts; the barnacle Balanus eburneus, bivalve mollusc Crassostrea virginica, and serpulid polychaete Hydroides dianthus at the Florida exposure site; and oysters Ostrea/Dendrostrea/Crassostrea spp. and the serpulid polychaete Hydroides elegans at the site in Pearl Harbor, Hawaii. Throughout the remainder of this paper the three species of oysters for which data were collected at the Hawaii site will be treated as a single functional group and referred to collectively by the common name 'oysters.' $C$. formicata failed to settle on several of the surface treatments; data were only collected for surfaces $1-2$ and $5-9$ at site NE1, and surfaces $1-4$ and $6-11$ at site NE2. All other species occurred on all of the surface treatments.

The removal stresses measured for $C$. fornicata were very low, ranging from a mean of $0.009 \mathrm{MPa}$ (surface \#9, NE1, Figure 1A) to $0.042 \mathrm{MPa}$ (surface \#3, NE2, Figure 1B). At both sites there were significant differences among the silicone treatments in the shear stress required to remove $C$. fornicata from the panel surface (NE1, $H=62.56, \mathrm{df}=6$, $p<0.0001$; NE2, $H=36.15, \mathrm{df}=9, p<0.0001$; Figure 1). Mean removal stresses at the two sites were not correlated $\left(\mathrm{r}_{\mathrm{Sp}}=0.6, n=6, p=0.21\right)$, although a positive trend was apparent that may have been rendered significant if individuals of C. fornicata had been available for testing on additional surface treatments.

The silicone surface treatments significantly affected removal stress for all of the species examined at the Florida site (B. eburneus, $H=745.73$; C. virginica, $H=90.07 ; H$. dianthus, $H=303.79$; $\mathrm{df}=11$ and $p<0.0001$ in all cases; Figure 2). The shear stress required to remove the barnacle $B$. eburneus (Figure 2A) was generally lower than that required to detach either oysters $C$. virginica (Figure 2C) or tubeworms $H$. dianthus (Figure 2B) (see also Kavanagh et al. 2001). Mean removal stresses for B. eburneus ranged from $0.024 \mathrm{MPa}$

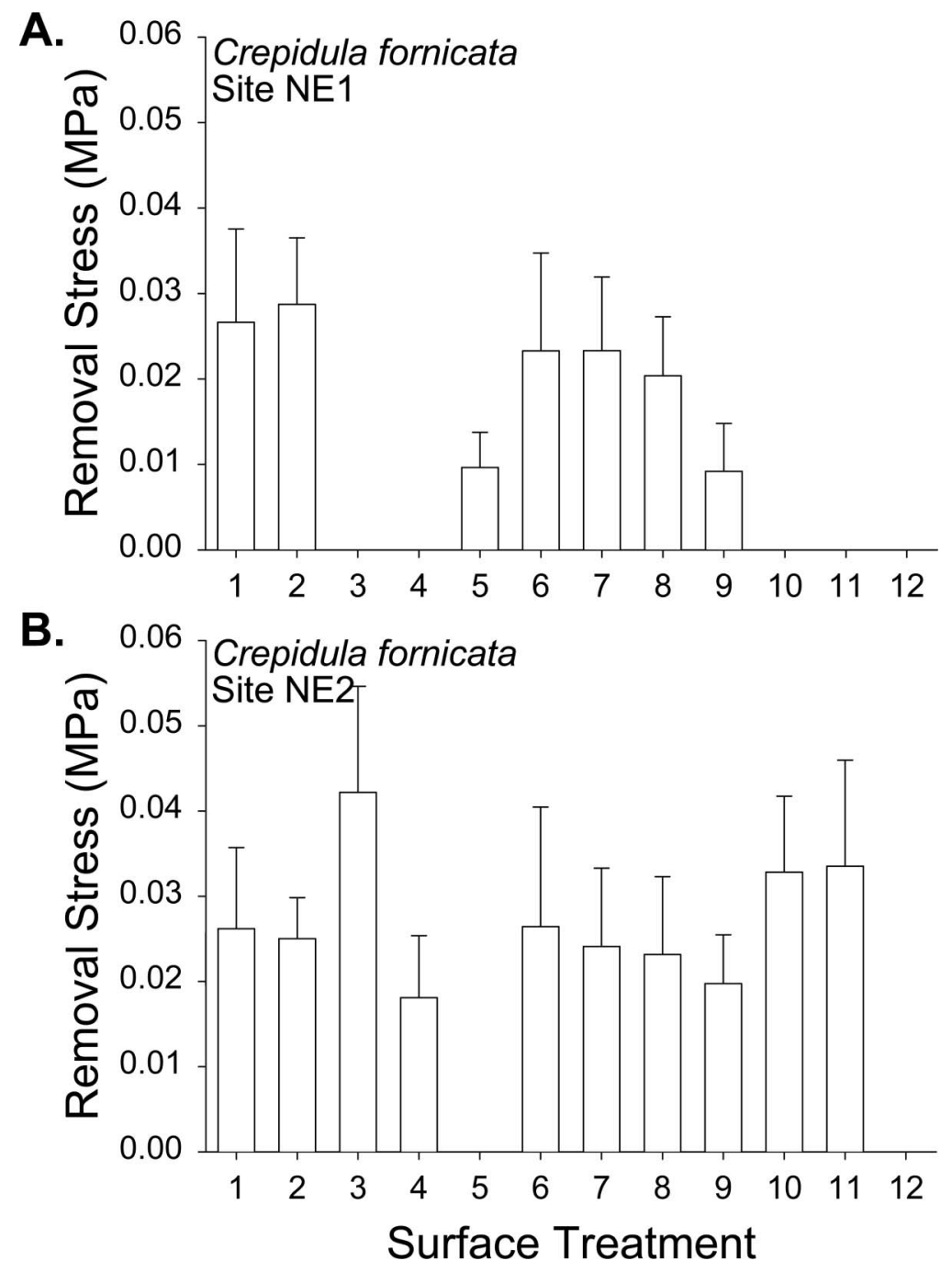

Figure 1. Mean values of shear stress required to remove the gastropod mollusc $C$. fornicata from test surfaces exposed at the Massachusetts test sites NE1 (A) and NE2 (B). Error bars = SDs. 


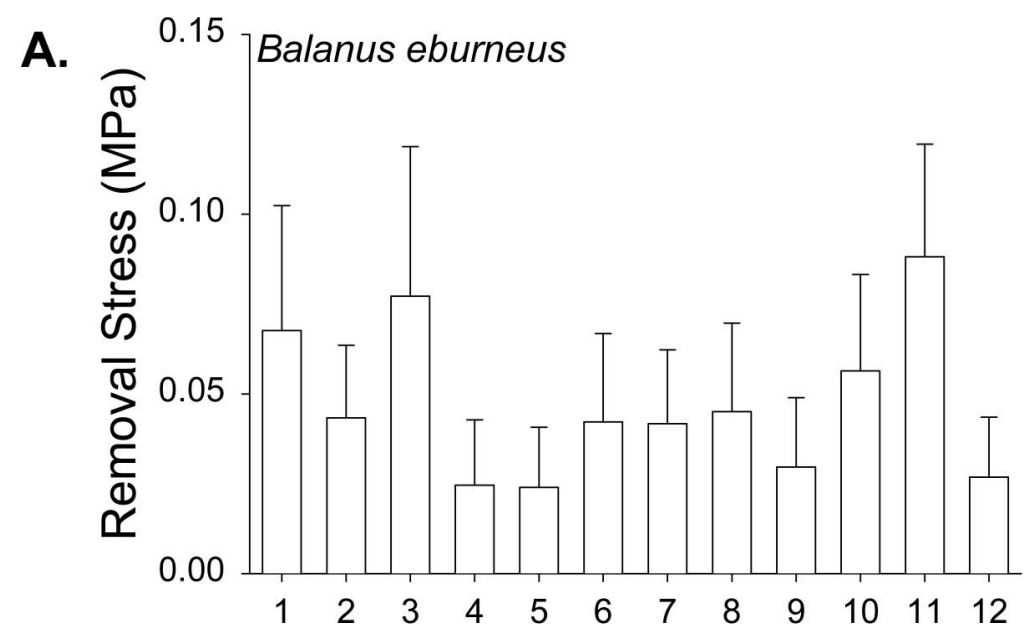

B.
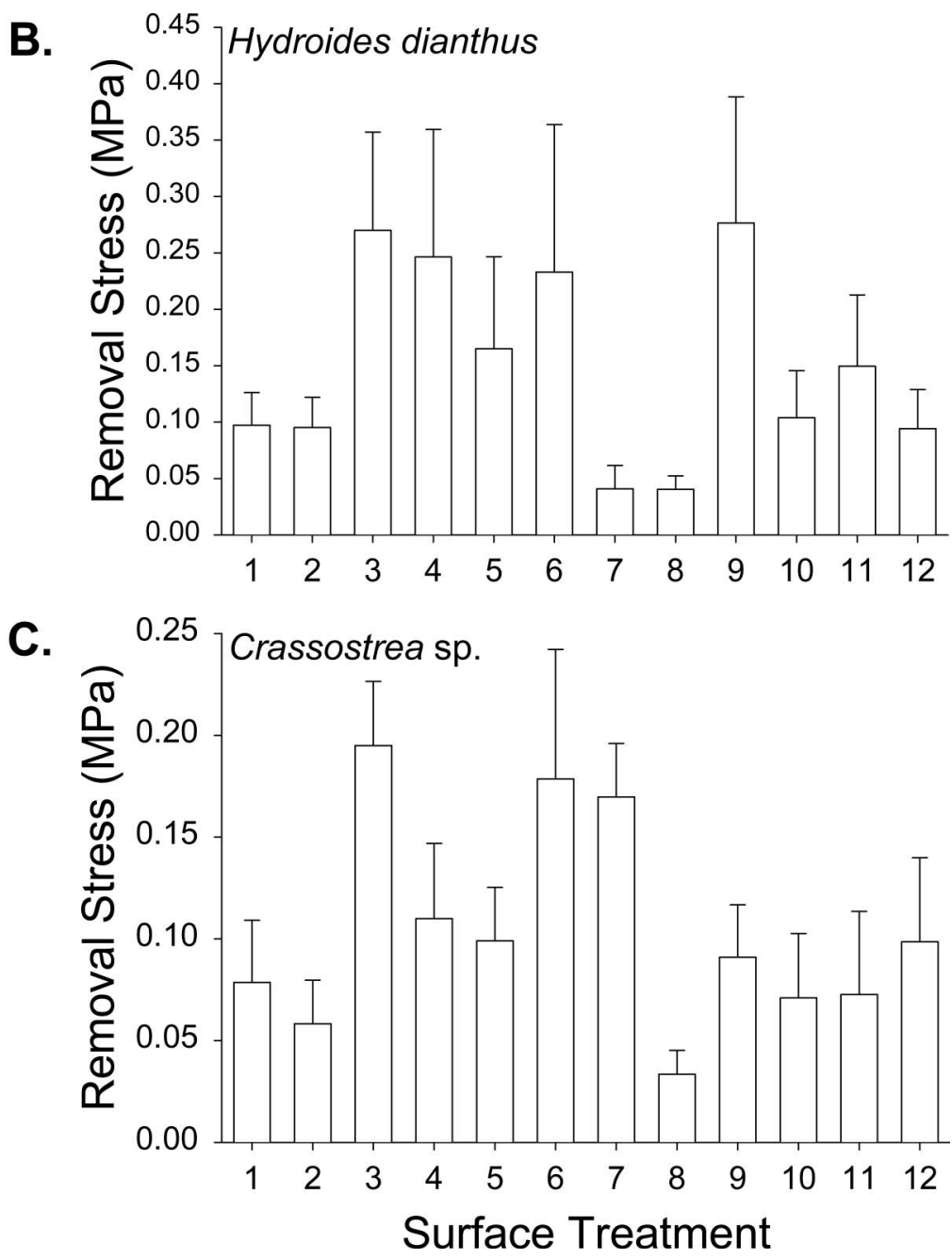

Figure 2. Mean values of shear stress required to remove the barnacle B. eburneus (A), the serpulid tubeworm $H$. dianthus (B) and the bivalve mollusc $C$. virginica $(\mathrm{C})$ from test surfaces exposed at the Florida test site. Error bars $=$ SDs.

(surface \#5) to $0.088 \mathrm{MPa}$ (surface \#11, Figure 2A); for $C$. virginica the range was from $0.033 \mathrm{MPa}$ (surface \#8) to $0.195 \mathrm{MPa}$ (surface \#3, Figure 2C), and for $H$. dianthus $0.04 \mathrm{MPa}$ (surface \#8) to $0.276 \mathrm{MPa}$ (surface \#9, Figure 2B). Mean removal stresses for the three species were uncorrelated.
Removal stresses measured for the group of oyster species (Figure 3B) and tubeworms $H$. elegans (Figure 3A) in Hawaii were also strongly affected by the silicone surfaces (oysters, $H=106.99$; $H$. elegans, $H=114.08 ; \mathrm{df}=11$ and $p<0.0001$ in both cases). Mean shear stresses required to remove 


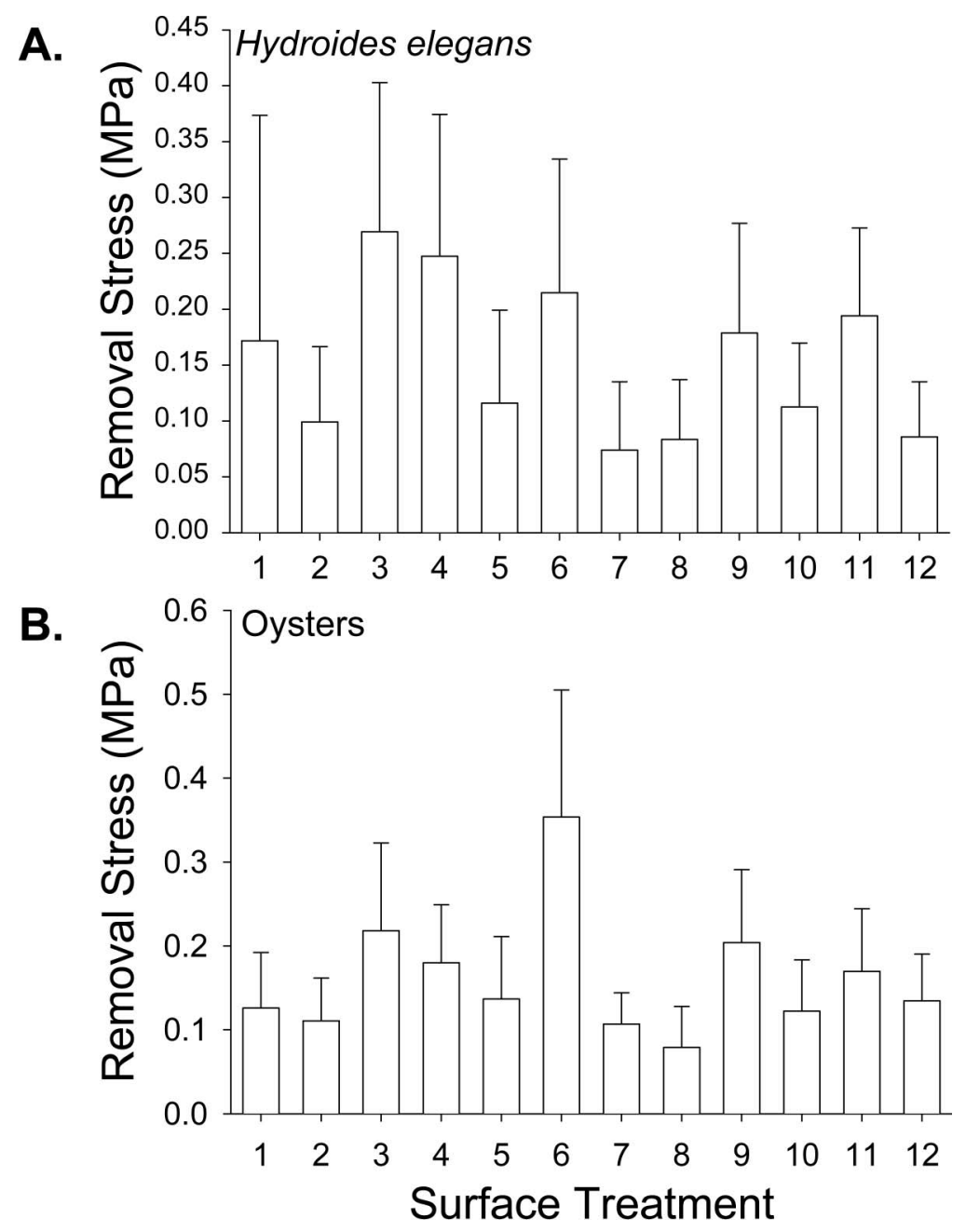

Figure 3. Mean values of shear stress required to remove the serpulid tubeworm H. elegans (A) and the bivalve molluscs Ostrea/Dendrostrea/ Crassostrea spp. (B) from test surfaces exposed at the Hawaii test site. Error bars $=$ SDs.

oysters were lowest on surface \#8 (0.079 $\mathrm{MPa})$ and highest on surface \#6 (0.354 MPa, Figure 3B), while for $H$. elegans the range in mean values was from $0.074 \mathrm{MPa}$ (surface \#7) to $0.269 \mathrm{MPa}$ (surface \#3, Figure 3A). Mean removal stresses were positively correlated for these two species $\left(\mathrm{r}_{\mathrm{Sp}}=0.89, \mathrm{n}=12\right.$, $P=0.0001$; Figure 4B).

\section{Comparisons between sites and principal component analysis of removal stress}

Comparisons between sites, of the mean removal stresses measured for each site's characteristic fouling species, yielded 4 significant correlations (out of 17 comparisons). The shear stress required to remove $C$. virginica in Florida was positively correlated with that required to remove oysters in Hawaii $\left(\mathrm{r}_{\mathrm{Sp}}=0.64, n=12, p=0.024\right.$; Figure $\left.4 \mathrm{~A}\right)$. Mean removal stresses for $H$. dianthus in Florida were positively correlated with mean removal stresses for both $H$. elegans $\left(\mathrm{r}_{\mathrm{Sp}}=0.88, n=12, p=0.0002\right.$; Figure $4 \mathrm{C})$ and oysters $\left(\mathrm{r}_{\mathrm{Sp}}=0.90, \quad n=12\right.$, $p<0.0001$; Figure 4D) in Hawaii. Mean removal stresses measured for B. eburneus, and C. formicata from site NE2, were also positively correlated $\left(\mathrm{r}_{\mathrm{Sp}}=0.84, n=10, p=0.0022\right.$; Figure $\left.4 \mathrm{E}\right)$.

A principal component analysis (PCA) was conducted using the mean removal stresses for all species for which measurements were available for every surface treatment (B. eburneus, $C$. virginica, $H$. dianthus, oysters [Hawaii], and $H$. elegans). The first two principal components produced by the analysis accounted for approximately $81.1 \%$ of the variance in the shear stress data, and reflected the correlations between mean removal stresses described above. The first component accounted for $59.5 \%$ of the variance, and was positively correlated to the shear stress required to remove the oysters and tubeworms (Table III). The second principal component accounted for $21.6 \%$ of the variance, and was positively correlated to mean removal stresses measured for B. eburneus (Table III). The remaining three principal components were uncorrelated to the mean removal stresses characteristic of any of the fouling species. 

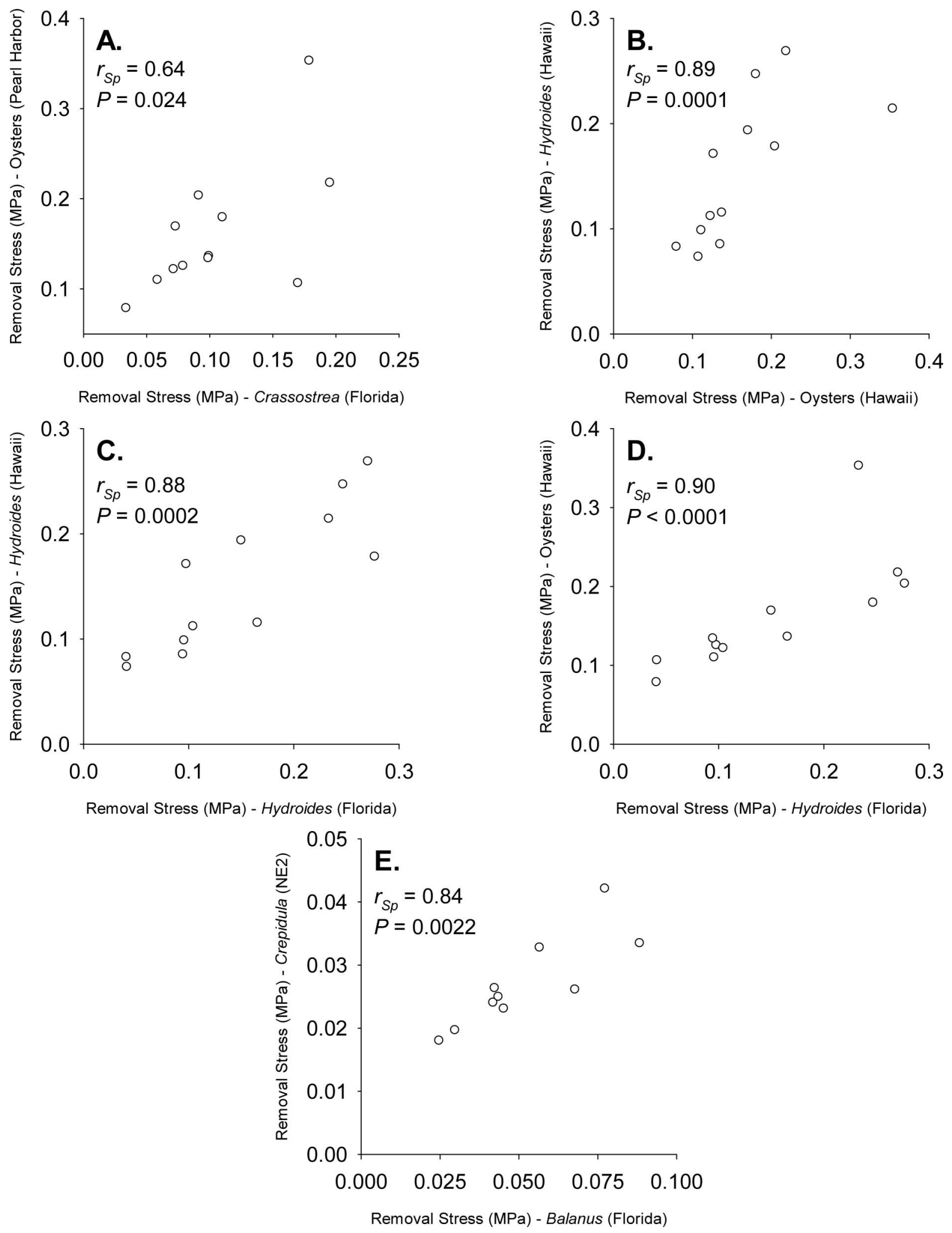

Figure 4. Correlations between mean removal stresses measured for different fouling organisms at the various field sites. Only comparisons producing significant $(p<0.05)$ Spearman rank correlations are shown. $\mathrm{r}_{\mathrm{Sp}}=$ Spearman's rank correlation coefficient; $p=$ probability $>\left|\mathrm{r}_{\mathrm{Sp}}\right|$.

None of the surface treatments represented a minimum in removal stress for all the fouling species tested (Figure 5). Surface treatments occurring in the lower left quadrant of the graph, however, represent materials for which adhesion of both classes of fouling organisms (as identified by PCA) was poor. Closer examination of Figure 5 suggests that the two groups of fouling organisms (tubeworms 
and oysters, barnacles) respond differently, in terms of their adhesion, to a subset of the materials tested. Surface treatments 4,6 , and 9 represent materials for which tenacity of barnacles is low, but tenacity of tubeworms and oysters is high, while treatments 1,8 , and 11 represent materials for which tenacity of barnacles is moderate to high while that of tubeworms and oysters is lower.

\section{Discussion}

The experimental silicone surfaces varied in their ability to prevent the strong adhesion of six different fouling species. As observed in other studies (for

Table III. Spearman rank correlations between the mean shear stresses required to remove particular fouling species from the surface treatments, and the principal components.

\begin{tabular}{lcc}
\hline Principal component & 1 & 2 \\
\hline B. eburneus & & 0.96 \\
H. dianthus & 0.89 & \\
C. virginica & 0.70 & \\
H. elegans & 0.92 & \\
Oysters (Hawaii) & 0.94 & \\
\hline
\end{tabular}

Only significant correlations $(p \leq 0.05)$ are listed, $n=12$ in all cases. 'Oysters (Hawaii)' potentially includes individuals of three species (see text). Mean shear stresses to remove C. fornicata from surface treatments at the NE2 site were significantly correlated to the second principal component $\left(\mathrm{r}_{\mathrm{Sp}}=0.75, n=10\right)$, but were not used in the calculation of the principal components themselves. example, Crisp et al. 1985; Swain et al. 1992; Becker, 1993; Kavanagh et al. 2001), the magnitude of the force required to remove an individual fouler also varied across species. C. fornicata (Figure 1) consistently required the lowest shear stress for detachment from the surface of a panel, followed by B. eburneus (Figure 2A), the bivalve molluscs (Figures 2C and 3B) and serpulid tubeworms (Figures 2B and 3A) (see also Kavanagh et al. 2001).

In order for a fouling-release coating to be globally effective, it must prevent strong adhesion by a diversity of fouling organisms that may manifest a diversity of adhesion mechanisms (Brady \& Singer, 2000). If rankings of the magnitude of removal stress for fouling-release materials were consistent across species, development of a globally effective foulingrelease material would potentially be relatively straightforward; the surface that produced the lowest value of removal stress for any one fouling species would produce the lowest value for all of them. The results presented above, however, show that while removal stress varied among species and among surface treatments (for all species tested), removal stress did not vary across surface treatments in the same way for all species. Correlations between the mean removal stresses, and the results of the principal component analysis on removal stress values, indicated that the fouling species examined fell into two independent groups (Table III). One group consisted of the bivalves $C$. virginica and Ostrea/Dendrostrea/Crassostrea spp. from Hawaii, and

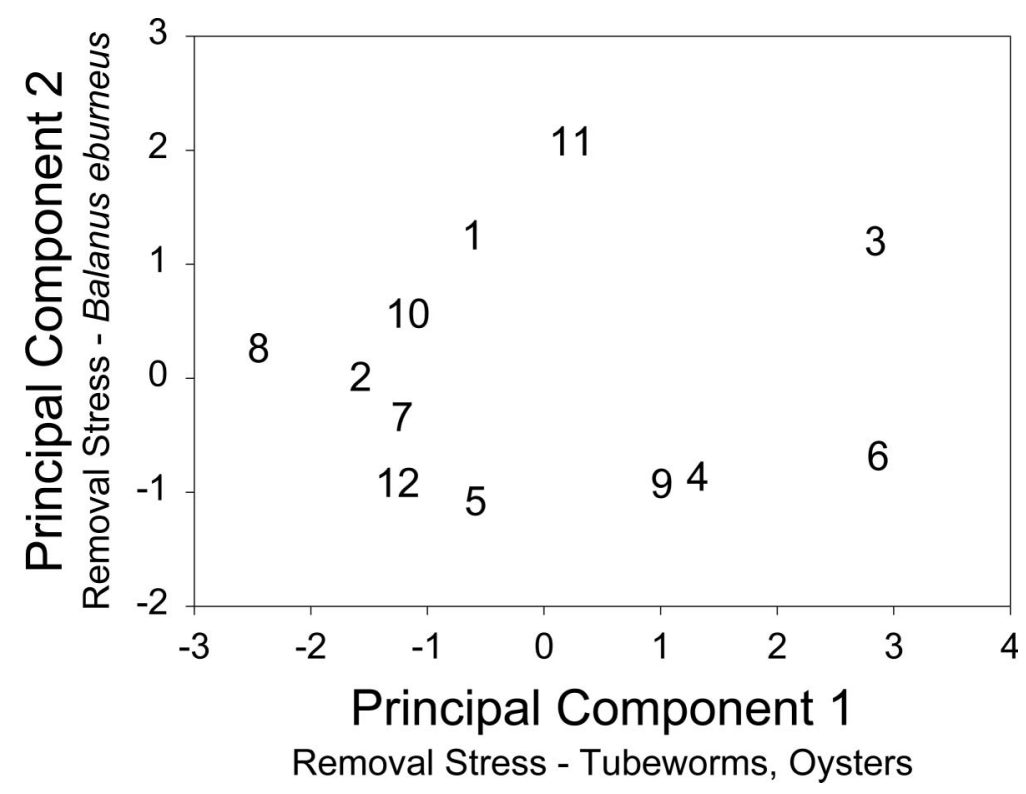

Figure 5. Clustering of the silicone surface treatments by their first two principal component scores, calculated from mean values of removal stress for the five fouling organisms (B. eburneus, C. virginica, H. dianthus, oysters [Hawaii], and H. elegans) for which data were available for every surface treatment. Principal component 1 is positively correlated with the removal stress observed for the bivalve molluscs and the tubeworms, while principal component 2 is positively correlated with the removal stress for the barnacle B. eburneus. Points within the graph represent the number of the corresponding silicone surface. Surface treatments occurring in the lower left quadrant of the graph produce low removal stresses (poor adhesion strength) for both classes of fouling organisms identified by the PCA. 
the tubeworms $H$. dianthus and H. elegans (Table III, Figure $4 \mathrm{~A}-\mathrm{D}$ ). The second group included the barnacle B. eburneus (Table III); C. fornicata may also fall into this group as mean removal stresses for this gastropod (at site NE2) were correlated to removal stresses for barnacles and to the second principal component derived from the shear stress data (Table III, Figure 4E).

The observation of two distinct classes of fouling organisms, defined by their ability to adhere to the silicone surface treatments, suggests the existence of at least two unique variables, associated with either or both the surface treatments or the fouling species, affecting organismal adhesion or mechanisms of adhesive failure. The identity of these variables is not apparent. Critical surface tension is an important determinant of the ability of a surface to reduce adhesion (Baier et al. 1968; Brady \& Singer, 2000). Effective fouling-release materials present critical surface tensions between $20-30 \mathrm{mN} \mathrm{m}^{-1}$ (Baier \& Meyer, 1992). All of the materials tested fell within this range before they were immersed. Recent studies have shown that the elastic modulus of a surface (Brady \& Singer, 2000; Berglin et al. 2003; Chaudhury et al. 2005) and thickness (Kohl \& Singer, 1999; Singer et al. 2000; Chaudhury et al. 2005; Wendt et al. 2006) can also affect the ease with which objects affixed to the surface may be removed. The thickness of the top coat varied across the experimental surfaces. It is not clear, however, whether or how this variation may have affected the patterns in removal stress that were observed. The removal stresses for all organisms tested at the same site were taken from the same set of panels, so relationships in mean removal stress between species, at the same test site, should be independent of variation in the test materials in thickness and elastic modulus, to the extent that these properties are homogeneous across the material surface, or are heterogeneous but undetectable to settling larvae.

Temporal variation in materials properties may also have affected the relationships observed between the species tested. The critical surface tensions of silicones and other materials change over time with immersion (Meyer et al. 1988; Nevell et al. 1996). Hydrophobic silicone substrata become more hydrophilic due to rearrangement of polymer chains at the material surface with penetration of water (Nevell et al. 1996). Recruitment of the fouling organisms that were evaluated, and growth to a testable size, varied among the surface treatments in time. Substantial heterogeneities in time between the evaluation of different fouling organisms on a particular substratum or among substrata could generate the patterns observed, if accompanied by changes in materials properties that affect adhesion. Darkangelo Wood et al. (2000) found no variation over time in the removal stress of barnacles or tubeworms at the Florida site for surface 1, and no variation over time in barnacle, tubeworm or oyster adhesion for surface 2. At the Hawaii site, however, removal stress of oysters decreased over time for both these materials, while removal stress of tubeworms increased with time for surface 1 (Darkangelo Wood et al. 2000).

On the basis of these results, it appears reasonable to propose that the patterns in variation that were observed in removal stress across the 12 surfaces, arose from species-specific interactions between organismal attachment mechanisms and the properties of the test materials, rather than solely to the physical or chemical properties of the materials. A rigorous test of this proposal will require laboratory measurements of removal stress for the subject fouling species, such that temporal variation in material properties can be controlled.

Common fouling organisms exhibit numerous and varied attachment strategies that may affect adhesion. Patterns of adhesion strength, and adhesives themselves, differ both inter- and intraspecifically. Spores of the green alga Ulva linza adhere less strongly to hydrophobic surfaces, while diatoms are removed more easily from hydrophilic materials (Finlay et al. 2002; Holland et al. 2004). The adhesive proteins of the barnacles B. eburneus and $B$. crenatus are different in composition and sequence from the adhesive proteins of the mussel $M$. edulis (Naldrett \& Kaplan, 1997). Individuals of $M$. edulis can potentially express at least 20 forms of Mefp3, a component of the mussel's adhesive plaque (Warner \& Waite, 1999). Mussels, however, do not appear to modify their adhesive in response to the surface to which they are attaching. Instead, they employ a similar subset of Mefp3 variants for all surfaces encountered, and the subset employed varies among individuals (Floriolli et al. 2000). Populations of the barnacle $B$. amphitrite harbor significant genetic variation for the morphology of their adhesive plaque when attached to silicone substrata (Holm et al. 2005), and the variation in morphology affects removal stress (Sun et al. 2004; Holm et al. 2005; Wendt et al. 2006). Perhaps due to the myriad of adhesion mechanisms likely expressed by the fouling organisms examined, none of the surfaces represented in this study generated a minimum in removal stress for all the fouling organisms tested (Figure 5). Several surfaces, however, did produce low values of removal stress for both the groups of fouling organisms defined by the principal component analysis. An effective fouling-release surface may not need to represent an absolute adhesion minimum for all fouling species, if removal stresses are reduced to the extent that sloughing of attached organisms, or self-cleaning, occurs at reasonable operating speeds. The reduction in removal stress 
necessary to facilitate sloughing will be a function of the form of the fouling organisms or fouling communities present on the surface, and the hydrodynamic forces they experience (Schultz et al. 1999). While development of improved fouling-release surfaces would benefit from further research on the nature of adhesives and the mechanics of adhesive failure (Kavanagh et al. 2001), investigations of the hydrodynamic forces experienced by fouling organisms (for example, Denny, 1995; Schultz et al. 1999) will reveal the maximum removal stresses permissible for selfcleaning during routine vessel operations.

\section{Acknowledgements}

This work was supported by DARPA contract N00014-96-C0145. The clarity of the presentation was improved by comments from R. E. Baier, M. E. Callow, M. A. R. Koehl, A. J. Underwood, and several anonymous reviewers.

\section{References}

Anonymous. 1997. ASTM D 5618-94. Standard test method for measurement of barnacle adhesion strength in shear. Annual book of ASTM standards. Vol. 06.02. West Conshohocken, PA: American Society for Testing and Materials.

Baier RE, Meyer AE. 1992. Surface analysis of fouling-resistant marine coatings. Biofouling 6:165-180.

Baier RE, Shafrin EG, Zisman WA. 1968. Adhesion: mechanisms that assist or impede it. Science 162:1360-1368.

Becker K. 1993. Attachment strength and colonization patterns of two macrofouling species on substrata with different surface tension (in situ studies). Mar Biol 117:301-309.

Berglin M, Lönn N, Gatenholm P. 2003. Coating modulus and barnacle bioadhesion. Biofouling 19(Suppl.):63-69.

Brady RF Jr, Singer IL. 2000. Mechanical factors favoring release from fouling release coatings. Biofouling 15:73-81.

Callow ME, Pitchers RA, Milne A. 1986. The control of fouling by non-biocidal systems. In: Evans LV, Hoagland KD, editors. Algal biofouling. Amsterdam: Elsevier Science Publishers. pp $145-158$.

Carlton JT, Hodder J. 1995. Biogeography and dispersal of coastal marine organisms: experimental studies on a replica of a 16thcentury sailing vessel. Mar Biol 121:721-730.

Chaudhury MK, Finlay JA, Chung JY, Callow ME, Callow JA. 2005. The influence of elastic modulus and thickness on the release of the soft-fouling green alga Ulva linza (syn. Enteromorpha linza) from poly(dimethylsiloxane) (PDMS) model networks. Biofouling 21:41-48.

Crisp DJ, Walker G, Young GA, Yule AB. 1985. Adhesion and substrate choice in mussels and barnacles. J Colloid Interface Sci 104:40-50.

Darkangelo Wood C, Truby K, Stein J, Wiebe D, Holm E, Wendt D, Smith C, Kavanagh C, Montemarano J, Swain G, Meyer A. 2000. Temporal and spatial variations in macrofouling of silicone fouling-release coatings. Biofouling 16:311-322.

Denny, M. 1995. Predicting physical disturbance: mechanistic approaches to the study of survivorship on wave-swept shores. Ecol Monogr 65:371-418.

Finlay JA, Callow ME, Ista LK, Lopez GP, Callow JA. 2002. The influence of surface wettability on the adhesion strength of settled spores of the green alga Enteromorpha and the diatom Amphora. Integr Comp Biol 42:1116-1122.
Floriolli, RY, von Langen J, Waite JH. 2000. Marine surfaces and the expression of specific byssal adhesive protein variants in Mytilus. Mar Biotechnol 2:352-363.

Godwin LS. 2003. Hull fouling of maritime vessels as a pathway for marine species invasions to the Hawaiian Islands. Biofouling 19(Suppl.):123-131.

Gollasch S. 2002. The importance of ship hull fouling as a vector of species introductions into the North Sea. Biofouling 18:105-121.

Griffith J. 1995. Nontoxic antifouling systems. US patent No. $5,449,553$.

Holland R, Dugdale TM, Wetherbee R, Brennan AB, Finlay JA, Callow JA, Callow ME. 2004. Adhesion and motility of fouling diatoms on a silicone elastomer. Biofouling 20:323-329.

Holm ER, Orihuela B, Kavanagh CJ, Rittschof D. 2005. Variation among families for characteristics of the adhesive plaque in the barnacle Balanus amphitrite. Biofouling 21:121-126.

Holm ER, Nedved BT, Phillips N, DeAngelis KL, Hadfield MG, Smith CM. 2000. Temporal and spatial variation in the fouling of silicone coatings in Pearl Harbor, Hawaii. Biofouling 15:95107.

Kavanagh CJ, Schultz MP, Swain GW, Stein J, Truby K, Darkangelo Wood C. 2001. Variation in adhesion strength of Balanus eburneus, Crassostrea virginica, and Hydroides dianthus to fouling-release coatings. Biofouling 17:155-167.

Kavanagh CJ, Swain GW, Kovach BS, Stein J, Darkangelo Wood C, Truby K, Holm E, Montemarano J, Meyer A, Wiebe D. 2003. The effects of silicone fluid additives and silicone elastomer matrices on barnacle adhesion strength. Biofouling 19:381-390.

Kohl JG, Singer IL. 1999. Pull-off behavior of epoxy bonded to silicone duplex coatings. Prog Org Coatings 36:15-20.

Manly BFJ. 1986. Multivariate statistical methods. New York: Chapman \& Hall.

Meyer AE, Baier RE, King RW. 1988. Initial fouling of nontoxic coatings in fresh, brackish, and sea water. Can J Chem Eng 66:55-62.

Naldrett MJ, Kaplan DL. 1997. Characterization of barnacle (Balanus eburneus and B. crenatus) adhesive proteins. Mar Biol 127:629-635.

Nevell TG, Edwards DP, Davis AJ, Pullin RA. 1996. The surface properties of silicone elastomers exposed to seawater. Biofouling 10:199-212.

SAS Institute Inc. 1989. SAS/STAT user's guide. Version 6, 4th ed. Cary NC: SAS Institute.

Schultz MP, Kavanagh CJ, Swain GW. 1999. Hydrodynamic forces on barnacles: implications on detachment from foulingrelease surfaces. Biofouling 13:323-335.

Singer IL, Kohl JG, Patterson M. 2000. Mechanical aspects of silicone coatings for hard foulant control. Biofouling 16:301309.

Stein J, Truby K, Darkangelo Wood C, Stein J, Gardner M, Swain G, Kavanagh C, Kovach B, Schultz M, Wiebe D, Holm E, Montemarano J, Wendt D, Smith C, Meyer A. 2003. Silicone foul release coatings: effect of the interaction of oil and coating functionalities on the magnitude of macrofouling attachment strengths. Biofouling 19(Suppl.):71-82.

Smith AM, Callow JA, editors. 2006. Biological adhesives. Berlin, Heidelberg: Springer. 284 pp.

Sun Y, Guo S, Walker GC, Kavanagh CJ, Swain GW. 2004. Surface elastic modulus of barnacle adhesive and release characteristics from silicone surfaces. Biofouling 20:279-289.

Swain GW, Schultz MP. 1996. The testing and evaluation of nontoxic antifouling coatings. Biofouling 10:187-197.

Swain GW, Nelson WG, Preedeekanit S. 1998. The influence of biofouling adhesion and biotic disturbance on the development of fouling communities on non-toxic surfaces. Biofouling 12:257-269. 
Swain GW, Griffith JR, Bultman JD, Vincent HL. 1992. The use of barnacle adhesion measurements for the field evaluation of non-toxic foul release surfaces. Biofouling 6:105-114.

Thieltges DW. 2005. Impact of an invader: epizootic American slipper limpet Crepidula fornicata reduces survival and growth in European mussels. Mar Ecol Prog Ser 286:13-19.

Truby K, Wood C, Stein J, Cella J, Carpenter J, Kavanagh C, Swain G, Wiebe D, Lapota D, Meyer A, Holm E, Wendt D, Smith C, Montemarano J. 2000. Evaluation of the performance enhancement of silicone biofouling-release coatings by oil incorporation. Biofouling 15:141-150.

Vincent HL, Bausch GG. 1997. Silicon fouling release coatings. Naval Research Rev 49:39-45.
Warner SC, Waite JH. 1999. Expression of multiple forms of an adhesive plaque protein in an individual mussel, Mytilus edulis. Mar Biol 134:729-734.

Wendt DE, Kowalke GL, Kim J, Singer IL. 2006. Factors that influence elastomeric coating performance: the effect of coating thickness on basal plate morphology, growth and critical removal stress of the barnacle Balanus amphitrite. Biofouling 22:1-9.

Wiegemann M. 2005. Adhesion in blue mussels (Mytilus edulis) and barnacles (genus Balanus): mechanisms and technical applications. Aquat Sci 67:166-176.

Woods Hole Oceanographic Institution. 1952. Marine fouling and its prevention. Annapolis, MD: United States Naval Institute. 